\title{
Morphometric Analysis Related to the Transcondylar Approach in Dry Skulls and Computed Tomography
}

\author{
Análisis Morfométrico del Acesso Transcondilar en Cráneos Secos y en Tomografia Computarizada \\ "Pereira, G. A. M.; "Lopes, P. T. C.; "Santos, A. M. P. V.; " Duarte, R. D.; **Piva, L. \& ${ }^{* * * *}$ Pozzobon, A.
}

PEREIRA, G. A. M.; LOPES, P. T. C.; SANTOS, A. M. P. V.; DUARTE, R. D.; PIVA, L.; POZZOBON, A. Morphometric analysis related to the transcondylar approach in dry skulls and computed tomography. Int. J. Morphol., 30(2):399-404, 2012.

SUMMARY: The transcondylar approach (TA) has been used in surgeries to access lesions in areas close to the foramen magnum (FM) and is performed directly through the occipital condyle (OC) or through the atlanto-occipital joint and adjacent portions of the same. The objective of this study is to examine anatomical variations related to the TA by morphometric parameters of the FM, OC and of the hypoglossal canal (HC) in dry skulls and in computed tomography (CT). In 111 skulls, characteristics of the HC, and measures related to the FM, the $\mathrm{HC}$ and to the $\mathrm{OC}$ were examined. In CT, the measurements obtained bilaterally in 10 patients who underwent examination of the skull base in $1 \mathrm{~mm}$-thick axial helical cuts were the distances from the outer half of the clivus to the opening of the $\mathrm{HC}$; from the lower portion of the $\mathrm{OC}$ to the middle of $\mathrm{HC}$; from the inner half of the clivus to the intracranial opening of the $\mathrm{HC}$ and to the midpoint of the $\mathrm{HC}$; from the $\mathrm{HC}$ extracranial opening to the lower portion of the OC and to the outer half of the clivus. The results of CT measurements are consistent to previous studies of morphometric variations related to the TA, with no significant difference between the measurements obtained in the right and in the left sides, or related to gender. The data obtained by three-dimensional CT images are important in assessing the morphometric variations of pre-surgical patientsof TA.

KEY WORDS: Transcondylar Approach; Computed Tomography; Hypoglossal Canal; Foramen Magnum; Occipital Condyle; Dry Skulls.

\section{INTRODUCTION}

The transcondylar approach (TA) has been used in surgeries to access lesions in areas close to the foramen magnum (FM) and it is performed directly through the occipital condyle (OC) or through the atlanto-occipital joint and adjacent portions of the same. The topographic relationship between a lesion and neurovascular structures is the most important characteristic when selecting the appropriate surgical procedure, and the identification of anatomical variations is crucial in the prior planning of neurosurgery (George et al., 1988; Kratimenos \& Crocard, 1993; Babu et al., 1994; Wen et al., 1997; Dowd et al., 1999; Rothon, 2000,; Nanda et al., 2002; Muthukumar et al., 2005; Barut et al., 2009).

Some approaches stemmed from the extreme lateral transcondylar approach, such as the transcondylar, the supracondylar, and the paracondilar approach, have been successfully performed to reduce the depth of the surgical area and improve the angle of exposure in these surgical procedures related to these approaches, reducing the amount of nerve tissue retraction required (Babu et al.; Dowd et al.).

The most common lesions found in the areas reached by these approaches are intra (Ammirati et al., 1993) and extradural tumors, vascular lesions of the vertebral artery and congenital lesions (Babu et al.; al-Mefty et al., 1996), aneurysms (Rohde et al., 1994) and meningiomas (Tange et al., 2001; Suhardja et al., 2003).

In the TA, the area of the lesion prior to the bone marrow and low-clivus can be reached by piercing the $\mathrm{OC}$ above the occipital junction, below the $\mathrm{HC}$ through the direct path of the OC. This type of approach decreases the depth of the surgical area and provides better visibility without brain retraction. Nevertheless, it is important to plan and calculate the bone extent to be resected (Barut et al.). Direct visualization of the spinal cord, the previous brain stem and the surface of the tumor can be achieved by the OC resection,

\footnotetext{
Universidade Luterana do Brasil, Laboratório de Anatomia Humana, Canoas, RS, Brasil.

${ }^{*}$ Fundação Saint Pastous/SERDIL, Porto Alegre, RS, Brasil

$\because *$ UNIVATES, Lajeado, RS, Brasil.
} 
which can be either wholly or partly (George et al.; Kratimenos \& Crocard; al-Mefty et al.). According to Spektor $e$ al. (2000), resection of the OC above the HC can improve the visual angle from 21 to $28 \%$ for the petroclival area, as well as provide an exposure increase from 28 to $71 \%$ by resecting the jugular tubercle.

The aim of this study was to analyze the anatomical variations of the bone structures related to the TA, showing important morphometric parameters of the FM, OC and the hypoglossal canal (HC) by studies of skulls and computed tomography $(\mathrm{CT})$.

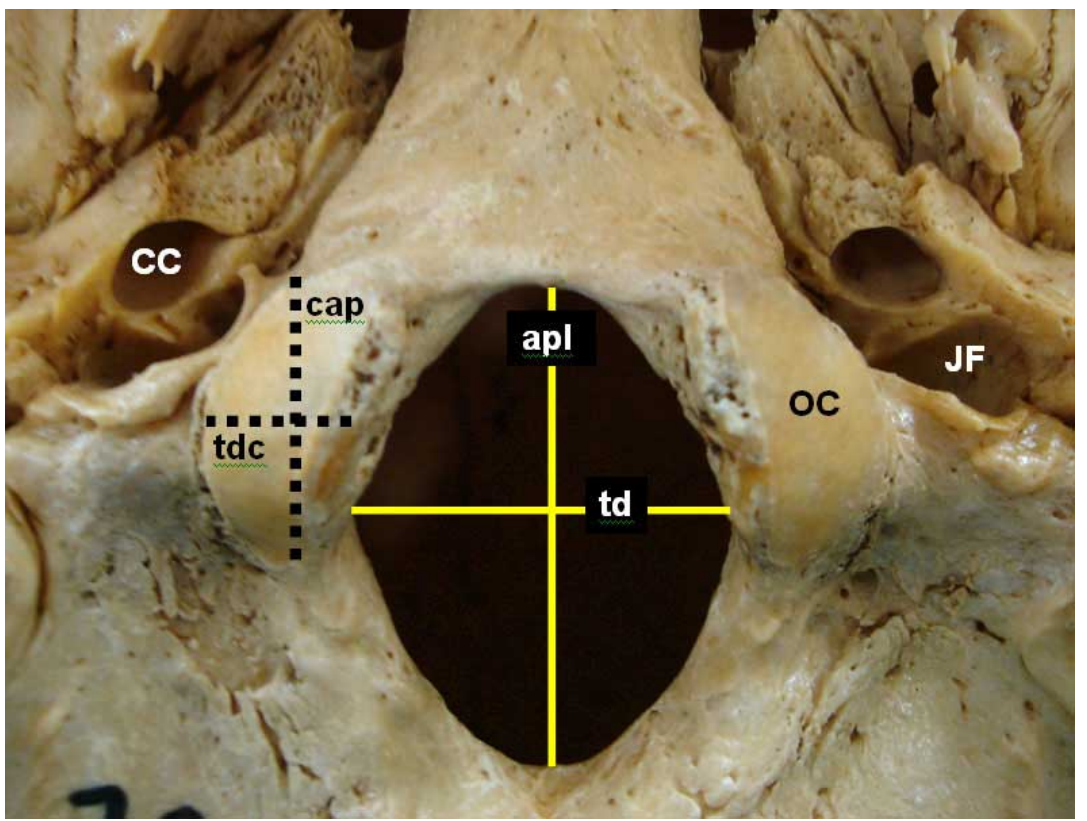

Fig. 1. Measures in dry skulls; apl (dashed line), anteroposterior length of the OC; tdc, transverse diameter of the OC; apl (solid line), anteroposterior length of the FM; td, transverse diameter of the FM; CC, carotid canal; JF, jugular foramen.

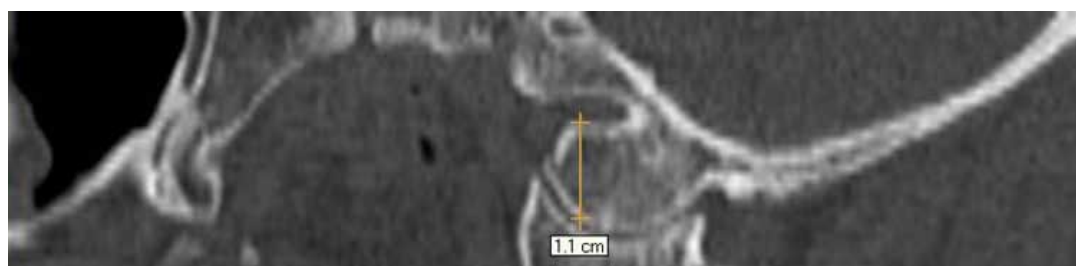

Fig. 2. Measurement in CT; B1-distance from the inferior portion of the $\mathrm{OC}$ to the extracranial opening of the $\mathrm{HC}$; right side.

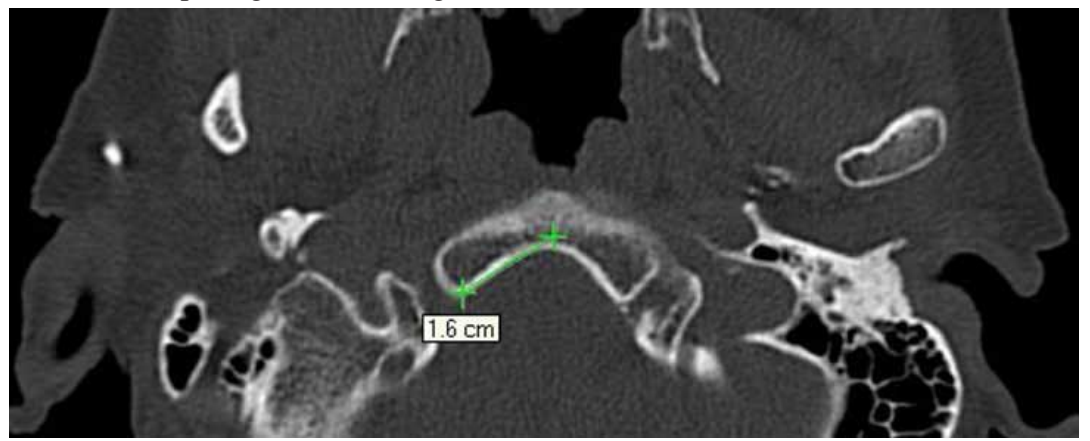

400

\section{MATERIAL AND METHOD}

Dry Skulls. 111 skulls, 88 male and 23 female, from the Laboratory of Human Anatomy of the Universidade Luterana do Brasil, Canoas, RS, were selected. 222 HCs, 222 OCs and 111 FMs were analyzed. The parameters studied bilaterally were the presence of septa in the HC, the presence and number of septa in each $\mathrm{HC}$, the size of the HC cavities formed by the septa, the FM anteroposterior and transverse diameters (Fig. 1), the OC transverse and anterolateral length (Fig. 1), the distance from the intracranial end of the $\mathrm{HC}$ to the anterior, posterior and inferior edge of the OC, the intra and extracranial diameter of the $\mathrm{HC}$, and the incidence of condylar foramina (CFs). Measurements were taken with Mitutoyo calipers and direct observation of structures.

Computed Tomography. The assessment related to the TA was performed in ten patients, three men and seven women, selected randomly, with no lesions involving the HC. The patients underwent 3D CT imaging of the cranial base using $1 \mathrm{~mm}$ axial helical slices and reconstruction interval on a Siemens Spirit Dual Slice equipment.

Measurements were taken bilaterally from each patient, completing 20 sides examined. The following distances were measured: from the lower portion of the $\mathrm{OC}$ to the extracranial opening of the HC (Fig. 2), from the outer half of the clivus to the opening of the $\mathrm{HC}$ (Fig. 3), from the lower portion of the OC to the midpoint of the HC ( Fig.4), from the outer half of the clivus to the extracranial opening of the HC (Fig. 5), from the inner half of the clivus to the intracranial opening of the HC (Fig. 6), and from the inner half of the clivus to the midpoint of the $\mathrm{HC}$ (Fig. 7).

Fig. 3. Measurement in CT, B2 - distance from the outer half of the clivus to the opening of the $\mathrm{HC}$; right side. 


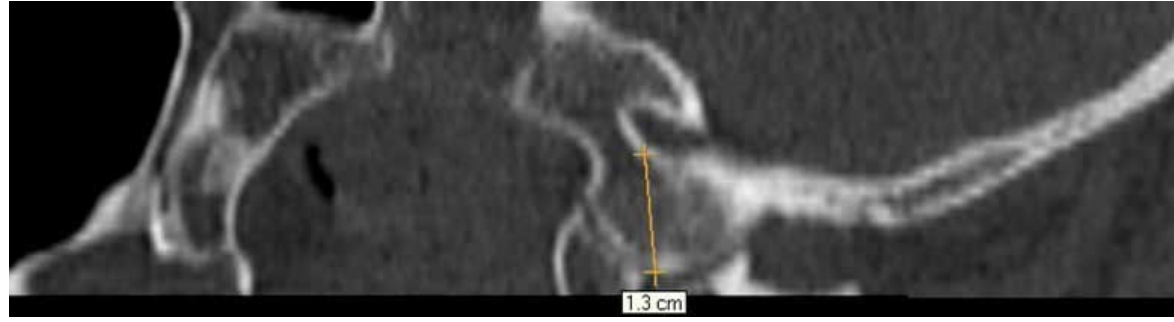

Fig. 4. Measurement in CT, B3 - distance from the inferior portion of the $\mathrm{OC}$ to the middle of the $\mathrm{HC}$; left side.

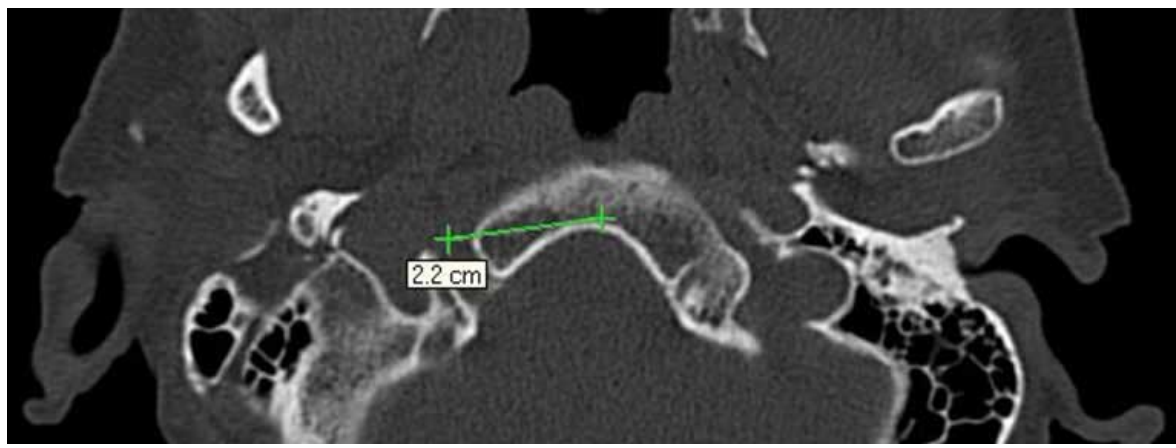

Fig. 5. Measurement in CT, B4 - distance from the outer half of the clivus to the extracranial opening of the $\mathrm{HC}$; right side.

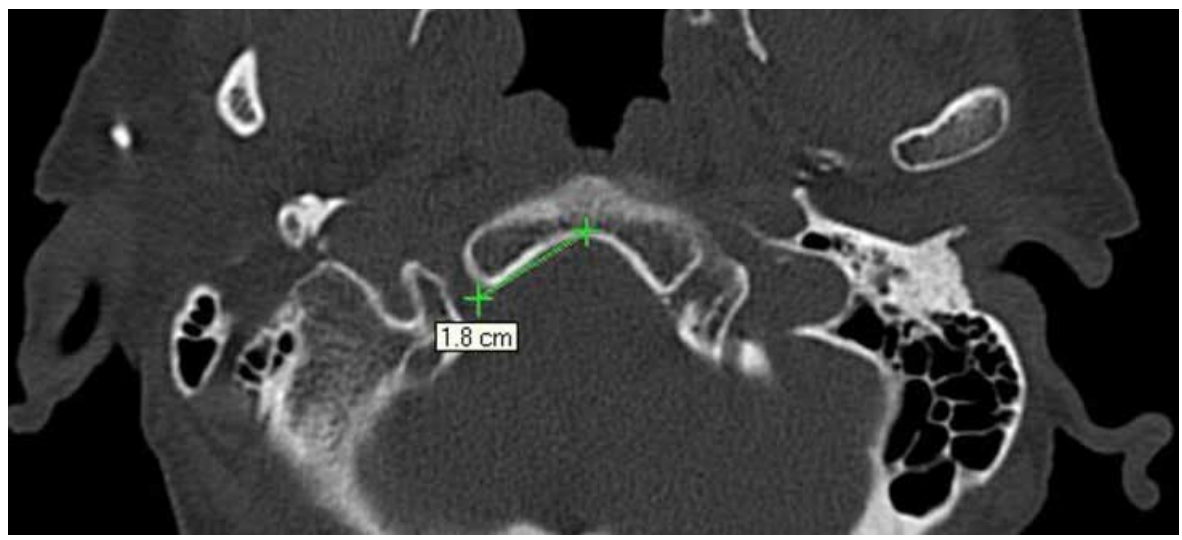

Fig. 6. Measurement in CT, B5 - distance from the inner half of the clivus to the intracranial opening of the $\mathrm{HC}$; right side.

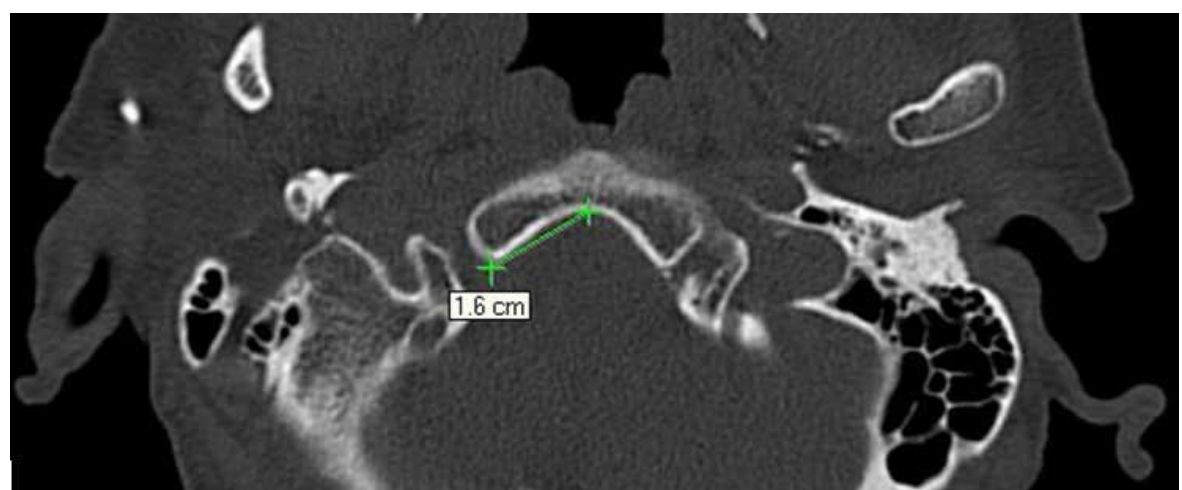

Fig. 7. Measurement in CT, B6 - distance from the inner half of the clivus to the midpoint of the $\mathrm{HC}$; right side.

\section{RESULTS AND DISCUSSION}

Dry skulls. Regarding the septa of the HC, $43.2 \%$ of skulls showed simple septum and $56.8 \%$ double septa, with the highest prevalence of septa in the right side $(65.8 \%)$. When the septa occur, the $\mathrm{HC}$ can be divided equally or unequally; inequitable forms reached $93.7 \%$ of skulls. There were no triple septa.

The FM mean index was 1.2 (standard deviation: 0.1), where the anteroposterior mean length was $36.0 \mathrm{~mm}(28.9 \mathrm{~mm}$ $43.1 \mathrm{~mm})$ and the mean width (transverse diameter) $30.5 \mathrm{~mm}$ (25.3 mm - $36.1 \mathrm{~mm})$. In $58.5 \%$ of the skulls, there were CFs on the right side, and in $65.9 \%$, on the left side. The results of other measurements related to the $\mathrm{OC}$ and the HC are shown in Table I.

Sen \& Sekhar (1991) consider that the handling of nervous tissue decreases as the amount of resection of $\mathrm{OC}$ increases. Wen et al. report that the distance between the posterior edge of the $\mathrm{OC}$ and the $\mathrm{HC}$ is approximately $8.4 \mathrm{~mm}$ and that a resection of the $\mathrm{OC}$ of that same amount would be sufficient for surgical exposure. Nanda et al. (2002) report that the total resection of the OC does not provide a significant increase in exposure and only allows greater freedom in the surgical procedure.

The measurements of the transverse diameter (Table I, A1) and the anteroposterior length of the OC (Table II, A2) are according to Barut et al., and differ from Nanda et al., who reported 9 $\mathrm{mm}$ for the transverse diameter.

Knowing the relation 
PEREIRA, G. A. M.; LOPES, P. T. C.; SANTOS, A. M. P. V.; DUARTE, R. D.; PIVA, L.; POZZOBON, A. Morphometric analysis related to the transcondylar approach in dry skulls and computed tomography. Int. J. Morphol., 30(2):399-404, 2012.

Table I. Descriptive statistics of variables in dry skulls (mm, n, min., max., mean, standard deviation).

\begin{tabular}{ccccccccccc}
\hline & & \multicolumn{3}{c}{ Right Side } & \multicolumn{3}{c}{ Left Side } \\
Measure & $n$ & Minimum & Maximum & Media & SD & $n$ & Minimum & Maximum & Media & SD \\
\hline A1 & 111 & 11.0 & 16.9 & 13.4 & 1.4 & 111 & 11.3 & 13.4 & 16.4 & 1.6 \\
A2 & 111 & 11.4 & 31.0 & 24.0 & 3.6 & 111 & 18.5 & 28.3 & 23.3 & 2.6 \\
A3 & 111 & 0.9 & 18.8 & 10.3 & 2.5 & 111 & 8.0 & 20.0 & 11.3 & 2.1 \\
A4 & 111 & 5.3 & 14.0 & 11.0 & 1.8 & 111 & 5.3 & 14.4 & 10.7 & 1.8 \\
A5 & 111 & 6.0 & 14.7 & 10.6 & 1.7 & 111 & 6.0 & 13.6 & 10.5 & 1.7 \\
A6 & 111 & 3.0 & 9.8 & 4.6 & 1.3 & 111 & 2.2 & 9.0 & 4.6 & 1.4 \\
A7 & 111 & 2.4 & 10.3 & 5.5 & 1.7 & 111 & 3.4 & 9.7 & 5.7 & 1.6 \\
\hline
\end{tabular}

$\mathrm{A} 1$, transverse diameter of the $\mathrm{OC}, \mathrm{A} 2$, anteroposterior length of the $\mathrm{OC}, \mathrm{A} 3$, distance from the intracranial ending of the $\mathrm{HC}$ to the posterior edge of the $\mathrm{OC}, \mathrm{A} 4$, distance from the intracranial ending of $\mathrm{HC}$ to the anterior edge of the $\mathrm{OC}, \mathrm{A} 5$, distance from the intracranial ending of the $\mathrm{HC}$ to the inferior edge of the OC, A6, intracranial diameter of the HC, A7, extracranial diameter of the HC.

Table II. Morphometric measurements (mm, mean \pm standard deviation) of the transcondylar approach in CT images.

\begin{tabular}{lcc}
\hline & Right Side & Left Side \\
\hline$B 1$ & $0.94 \pm 0.04$ & $0.94 \pm 0.04$ \\
$B 2$ & $1.80 \pm 0.05$ & $1.72 \pm 0.05$ \\
$B 3$ & $1.14 \pm 0.06$ & $1.06 \pm 0.04$ \\
$B 4$ & $2.22 \pm 0.04$ & $2.08 \pm 0.05$ \\
$B 5$ & $1.68 \pm 0.04$ & $1.60 \pm 0.05$ \\
$B 6$ & $1.63 \pm 0.03$ & $1.57 \pm 0.06$ \\
\hline
\end{tabular}

$\mathrm{B} 1$, distance from the inferior portion of the $\mathrm{OC}$ to the extracranial opening of the $\mathrm{HC}, \mathrm{B} 2$, distance from the outer half of the clivus to the opening of the HC; $\mathrm{B} 3$, distance from the inferior half of the $\mathrm{OC}$ to the midpoint of the $\mathrm{HC}$; B4, distance from the outer half of the clivus to the extracranial opening of the $\mathrm{HC}$; $\mathrm{B} 5$, distance from the inner half of the clivus to the intracranial opening of the $\mathrm{HC}$; $\mathrm{B} 6$, distance from the inner half of the clivus to the midpoint of the HC.

between the $\mathrm{HC}$ and the $\mathrm{OC}$ is crucial in the TA (Bozbuga et al., 1998), and the OC maximum pierceable amount without opening the posterior edge of the $\mathrm{HC}$ is $1 / 3$ or $1 / 2$ posterior of the long axis of the OC (Rhoton; Marin Sanabria et al. 2002; Tatagiba et al., 2006). The values of $10.3 \mathrm{~mm}$ on the right side, and of $11.3 \mathrm{~mm}$ on the left side for the mean distance between the $\mathrm{HC}$ and the posterior edge of the OC, found in this study (Table I, A3), are close to the values reported by Muthukumar et al. and Barut et al., and different from Wen et al., who reported $8.4 \mathrm{~mm}$. The values of $11.0 \mathrm{~mm}$ (right side) and $10.7 \mathrm{~mm}$ (left side) for the mean distance between the $\mathrm{HC}$ and the anterior edge of the OC (Table I, A4) are also in accordance to the values reported by Muthukumar et al. and Barut et al. The structure of the septum of the $\mathrm{HC}$ must also be examined, because if two or three parts of the canal are not identified prior to surgery, the nerve of the $\mathrm{HC}$ can be injured (Katsuta et al.,
2000). $43.2 \%$ of the skulls examined had simple septum and $56.8 \%$ had double septa. The prevalence of septa in the $\mathrm{HC}$ was higher on the right side (65.8\%). 25 and $30 \%$ of the HCs with a single septum were reported by Barut et al. and Muthukumar et al., respectively. Triple septa were not found in any of the studies mentioned. The single septa divided the $\mathrm{HC}$ in unequal parts in $93.7 \%$ of the skulls, results consistent to those of Barut et al. and Muthukumar et al. The FM index is calculated by dividing the anteroposterior diameter by the transverse diameter. When the index value is equal to or greater than 1.2, the shape of the foramen is considered oval. In lesions in the anterior portions of the brain stem, if the FM is oval, a wider resection is required, as compared to a circular shape (Muthukumar et al.). The mean index of the FM was 1.2 (standard deviation: 0.1), where the mean anteroposterior length was $36.0 \mathrm{~mm}(28.9 \mathrm{~mm}-43,1 \mathrm{~mm})$, and the mean width (transverse diameter) was $30.5 \mathrm{~mm}$ (25.3-36 mm, 1 $\mathrm{mm}$ ), results that are similar to those found by Barut et al. The CF is located in the condylar fossa, posterior to the $\mathrm{OC}$, and is one of the broadest emissary foramina, which can be seen in pre-surgical image (Ginsberg, 1994). The posterior condylar vein leaves the skull through the posterior condylar canal and it is an alternative source in a dysfunction of the venous drainage of the sigmoid-jugular complex. When obliterated during surgery, it can lead to fatal results (Thompson et al., 1995). The present study indicated the presence of CFs in $58.5 \%$ of the skulls on the right side, and in $65.9 \%$ on the left side, as the results of Barut et al., and unlike Muthukumar et al., who reported prevalence of CFs on the right side. Ginsberg identified CFs unilaterally in 50\% of the cases and bilaterally in $30 \%$.

Computed Tomography. Results are shown in Table II and Figures 1 to 7, with no significant differences in regard to sex. The laterality was significantly different between the right and left sides only in the measurement shown in 
B1 (Table II). Pre-surgical evaluation has been supported by radiological CT images, which are used extensively in the recognition, evaluation and study of morphometric parameters related to the TA (Matsushima et al. 2001; Day, 2004; Huynh-Le et al., 2004; Liu \& Coudwell, 2005; Bulsara et al. 2008; Menezes, 2008; Sen et al., 2010). Likewise, the evaluation and post-surgical follow-up need this resource. In addition, cadaver studies are also conducted to record the anatomical variations of the areas accessed in these procedures (Matsushima et al., 2010; Wu et al., 2010).

The results of measurements in CT (Table II) are consistent to the data obtained by Bulsara et al., who performed the same measurements related to the clivus,
HC and OC. These authors found no significant differences in laterality in any of the measurements. Like the results of these authors, there was no significant difference in any of the measurements taken in relation to gender in this study.

Most of the data obtained in dry skulls and CT corroborate previous studies and are important parameters in the evaluation of morphometric variations of pre-surgical patients in regard to the transcondylar approach, thus helping to reduce the risk of neurovascular injury during the procedure, and also, it highlights the importance of three-dimensional CT image and contributes to the data survey of the population of southern Brazil.

PEREIRA, G. A. M.; LOPES, P. T. C.; SANTOS, A. M. P. V.; DUARTE, R. D.; PIVA, L.; POZZOBON, A. Análisis morfométrico del acesso transcondilar en cráneos secos y en tomografia computarizada. Int. J. Morphol., 30(2):399-404, 2012.

RESUMEN: El acceso transcondilar (AT) ha sido utilizado como un procedimiento quirúrgico para lesiones cercanas al foramen magnum (FM) y se realiza directamente a través del cóndilo occipital (CO) o por medio de las porciones atlanto-occipital conjunta y adyacentes de la misma. El objetivo del presente estudio fue examinar las variaciones anatómicas relacionadas con el AT mediante los parámetros morfométricos del FM, CO y el canal del hipogloso $(\mathrm{CH})$ en cráneos secos y tomografía computadorizada (CT). En 111 cráneos fueron examinadas las características del $\mathrm{CH}$ y tomadas medidas relacionadas con el FM, CO y CH. En la CT, las mediciones se obtuvieron de forma bilateral en 10 pacientes que se sometieron a exámen de la base del cráneo en corte axial helicoidal de $1 \mathrm{~mm}$ de espesor. Las medidas tomadas fueron las distancias: de la mitad exterior del clivus a la apertura del $\mathrm{CH}$; de la parte inferior de las emisiones de $\mathrm{CO}$ a la mitad del $\mathrm{CH}$; de la mitad interna del clivus a la apertura intracraneal del $\mathrm{CH}$ y hasta el punto medio del $\mathrm{CH}$; de la apertura extracraneal del $\mathrm{CH}$ a la parte inferior de las emisiones de $\mathrm{CO}$ y hasta la mitad exterior del clivus. Los resultados de las mediciones de CT son consistentes con estudios prévios de los cambios morfométricos en relación con AT, sin diferencia significativa entre las mediciones obtenidas en el lado derecho e izquierdo y ni en relación con el sexo. Los datos obtenidos a través de imágenes en tres dimensiones de CT son importantes para evaluar las variaciones morfométricas de pre-quirúrgicos en el AT.

PALABRAS CLAVE: Acceso transcondilar; Tomografía computadorizada; Canal del hipogloso; Foramen magnum; Cóndilo occipital; Cráneos secos.

\section{REFERENCES}

Al-Mefty, O; Borba, L. A; Aoki, N.; Angtuaco, E. \& Pait, T. G. The transcondylar approach to extradural non-neoplasic lesions of the craniovertebral junction. J. Neurosurg., 84(1):1-6, 1996.

Ammirati, M.; Ma, J.; Canalis, R.; Martin, N., Black, K.; Cheatham, M.; Bloch, J. \& Becker, D. A combined intradural presigmoidtranstransversarium-transcondylar approach to the whole clivus and anterior craniospinal region: anatomic study. Skull Base Surg., 3(4):193-200, 1993.

Babu, R. P.; Sekhar, L. N. \& Wright, D. C. Extreme lateral transcondylar approach: technical improvements and lessons learned. J. Neurosurg., 81(1):49-59, 1994.

Barut, N.; Kale, A.; Suslu, H. T.; Ozturk, A.; Bozbuga, M. \& Sahinoglu, K. Evaluation of the bony landmarks in transcondylar approach. Br. J. Neurosurg., 23(3):276-81, 2009.
Bozbuga, M.; Oztürk, A.; Ari, Z.; Sahinoglu, K.; Bayraktar, B.; Polat, G. \& Gürel, I. Surgical anatomy of the temporal bone and measurements of the skull base for transpetrosal approaches. Okajimas Folia Anat. Jpn., 75(1):33-9, 1998.

Bulsara, K. R.; Asaoka, K.; Aliabadi, H.; Kanaly, C.; Friedman, A. \& Fukushima, T. Morphometric three-dimensional computed tomography anatomy of the hypoglossal canal. Neurosurg. Rev., 31(3):299-302, 2008.

Day, J. D. Intradural jugular tubercle reduction to enhance exposure via the transcondylar approach: technical note. Neurosurgery, 55(1):247-50, 2004.

Dowd, G. C.; Zeiller, S. \& Awasthh, D. Far lateral transcondilar approach: dimensional anatomy. Neurosurgery, 45(1):95-100, 1999. 
George, B.; Dematons, C. \& Cophignon, J. Lateral approach to the anterior portion of the foramen magnum. Application to surgical removal of 14 benign tumors: technical note. Surg. Neurol., 29(6):484-90, 1988.

Ginsberg, L. E. The posterior condylar canal. AJNR Am. J. Neuroradiol., 15(5):969-72, 1994.

Huynh-Le, P.; Matsushima, T.; Miyazono, M.; Sayama, T.; Muratani, H.; Tashima, T. \& Sasaki, T. Three-dimensional CT angiography for the surgical management of the vertebral artery-posterior inferior cerebellar artery aneurysms. Acta Neurochir. (Wien), 146(4):329-35, 2004.

Katsuta, T.; Matsushima, T.; Wen, H. T. \& Rhoton, A. L. Trajectory of the hypoglossal nerve in the hypoglossal canal: significance for the transcondylar approach. Neurol. Med. Chir. (Tokyo), 40(4):206-10, 2000.

Kratimenos, G. P. \& Crocard, H. A. The far lateral approach for ventrally placed foramen magnum and upper cervical spine tumours. Br. J. Neurosurg., 7(2):129-40, 1993.

Liu, J. K. \& Coudwell, W. T. Far-lateral transcondylar approach: surgical technique and its application in neuroenteric cysts of the cervicomedullary junction. Neurosurg. Focus, 19(2):E9, 2005.

Matsushima, T.; Kawashima, M.; Masuoka, J.; Mineta, T. \& Inoue, T. Transcondylar fossa (supracondylar transjugular tubercle) approach: anatomic basis for the approach, surgical procedures, and surgical experience. Skull Base, 20(2):83-91, 2010.

Matsushima, T.; Matsukado, K.; Natori, Y.; Inamura, T.; Hitotsumatsu, T. \& Fukui, M. Surgery on a saccular vertebral artery-posterior inferior cerebellar artery aneurysm via the transcondylar fossa (supracondylar transjugular tubercle) approach or the transcondylar approach: surgical results and indications for using two different lateral skull base approaches. J. Neurosurg., 95(2):268-74, 2001.

Menezes, A. H. Surgical approaches: postoperative care and complications "transoral-transpalatopharyngeal approach to the craniocervical junction". Childs Nerv. Syst., 24(10):1187-93, 2008.

Muthukumar, N.; Swaminathan, R.; Venkatesh, G. \& Bhanumathy, S. P. A morphometric analysis of the foramen magnum region as it relates to the transcondilar approach. Acta Neurochir. (Wien), 147(8):889-95, 2005.

Nanda, A.; Vincent, D. A.; Vannemreddy, P. S. S.; Baskaya, M. \& Chanda, A. Far-lateral approach to intradural lesions of the foramen magnum without resection of the occipital condyle. J. Neurosurg., 96(2):302-9, 2002.

Rhoton, A. L. Jr. The far-lateral approach and its transcondilar, supracondylar, and paracondylar extensions. Neurosurgery, 47(3 Suppl):S195-209, 2000.
Rohde, V.; Schaller, C. \& Hassler, W. The extreme lateral transcondylar approach to aneurysms of the vertebrobasilar junction, the vertebral artery, and the posterior inferior cerebellar artery. Skull Base Surg., 4(4):177-80, 1994.

Sanabria, M. E. A.; Ehara, K. \& Tamaki, N. Surgical experience with skull base approaches for foramen magnum meningioma. Neurol. Med. Chir. (Tokyo), 42(11):472-80, 2002.

Sen, C. N. \& Sekhar, L. N. Surgical management of anteriorly placed lesions at the craniocervical junction - an alternative approach. Acta Neurochir. (Wien), 108(1-2):70-7, 1991.

Sen, C.; Shrivastava, R.; Anwar, S. \& Triana, A. Lateral transcondylar approach for tumors at the anterior aspect of the craniovertebral junction. Neurosurgery, 66(3 Suppl):104-12, 2010.

Spektor, S.; Anderson, G. J.; McMenomey, S. O.; Horgan, M. A.; Kellog, J. X. \& Deshaw, J. B. Jr. Quantitative description of the far lateral transcondilar transtubercular approach to the foramen magnum and clivus. J. Neurosurg, 92(5):824-31, 2000.

Suhardja, A.; Agur, A. \& Cusimano, M. D. Anatomical basis of approaches to foramen magnum and lower clival meningiomas: comparison of retrosigmoid and transcondylar approaches. Neurosurg. Focus, 14(6):e9, 2003.

Tange, Y.; Uto, A.; Wachi, A. \& Koike, J. Transcondilar fossa approach to treat ventral foramen magnum meningioma. Neurol. Med. Chir. (Tokyo), 41(9):458-62, 2001.

Tatagiba, M.; Koerbel, A. \& Roser, F. The midline suboccipital subtonsilar approach to the hypoglossal canal: surgical anatomy and clinical application. Acta Neurochir. (Wien), 148(9):965-9, 2006.

Thompson, D. N.; Hayward, R. D.; Harkness, W. J.; Bingham, R. M. \& Jones, B. M. Lessons from a case of kleeblattschädel. Case report. J. Neurosurg., 82(6):1071-4, 1995.

Wen, H. T.; Rhoton, A. L. Jr.; Katsuta, T. \& de Oliveira, E. Microsurgical anatomy of the transcondilar, supracondilar and paracondilar extensions of the far lateral approach. $J$. Neurosurg., 87(4):555-85, 1997.

Wu, A.; Zabramski, J. M.; Jittapiromsak, P.; Wallace, R. C.; Spetzler, R. F. \& Preul, M. C. Quantitative analysis of variants of the far lateral approach: condylar fossa and transcondylar exposures. Neurosurgery, 66(6 Suppl. Operative):191-8, 2010.

\section{Correspondence to: \\ Paulo Tadeu Campos Lopes \\ Universidade Luterana do Brasil \\ Laboratório de Anatomia Humana \\ Av. Farroupilha, 8001, CEP 92425-900 \\ Canoas, RS \\ BRASIL}

Received: 24-10-2011

Email: pclopes@ulbra.br 